\title{
Effects of DGAT1 K232A polymorphism and milking frequency on milk composition and spontaneous lipolysis in dairy cows
}

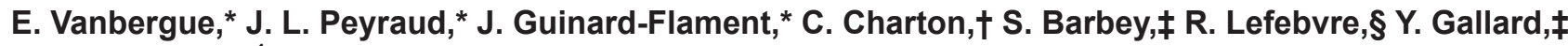 \\ and C. Hurtaud*1 \\ *PEGASE, INRA, Agrocampus Ouest, 35590, Saint-Gilles, France \\ †GenPhySE, Université de Toulouse, INRA, INPT, INP-ENVT, Castanet Tolosan, France \\ ‡DEP, INRA, 61310, Exmes, France \\ $\S \mathrm{GABI}$, AgroParisTech, INRA, Université Paris-Saclay, 78350, Jouy-en-Josas, France
}

\section{ABSTRACT}

Milk spontaneous lipolysis (SL) of milk triglycerides is induced by the lipoprotein lipase, a milk native enzyme, and leads to an accumulation of partial glycerides and free fatty acids that are responsible for the deterioration of the taste of milk products. The gene coding for diacylglycerol acyltransferase 1 (DGAT1), an enzyme implicated in triglycerides synthesis, has an important polymorphic site at the K232A locus. This gene is well known to modulate milk composition. No data are available on the effects of DGAT1 on SL. Thus, a trial was carried out to evaluate the effects of DGAT1 K232A polymorphism on milk SL upon milking frequency variations [once- (ODM) and twice-daily milking (TDM)]. Twenty-one cows were divided into 3 groups according their DGAT1 K232A genotype: 8 cows had the $K K$ genotype of DGAT1 ( $K K$ cows), 8 had the $K A$ genotype ( $K A$ cows), and 5 had the $A A$ genotype ( $A A$ cows). The trial consisted in 3 successive periods: 3 wk of TDM, 3 of ODM, and 4 of TDM. Samples were collected for fat and protein contents, SL, fatty acid, and protein profiles determinations. The $K K$ cows presented higher fat and protein contents, lower milk production, and higher $\kappa$-casein percentage. No significant difference in fatty acid composition was noted between groups. The SL was twice as high for $K K$ cows in TDM situations (1.13 vs. 0.59 and $0.63 \mathrm{mEq} / 100 \mathrm{~g}$ of fat, respectively, for $K K, K A$, and $A A$ cows during the first period of TDM, and 0.46 vs. 0.25 and $0.21 \mathrm{mEq} / 100$ $\mathrm{g}$ of fat, respectively, for $K K, K A$, and $A A$ during the second period of TDM). The SL remained lower in TDM2 than in TDM1. During ODM, no difference in SL was found between groups and SL remained below $0.2 \mathrm{mEq} / 100 \mathrm{~g}$ of fat. These results demonstrate the

Received December 7, 2015

Accepted March 23, 2016.

${ }^{1}$ Corresponding author: Catherine.Hurtaud@rennes.inra.fr existence of a correlation between DGAT1 genotypes and spontaneous lipolysis, in interaction with an environmental factor, milking frequency, although it has not been possible to clarify the causal mechanism at this stage.

Key words: spontaneous lipolysis, once-daily milking, DGAT1, dairy cow, milk composition

\section{INTRODUCTION}

Milk lipolysis is the hydrolysis of triglycerides, the major lipid components of milk, by lipoprotein lipase (LPL), a milk native enzyme. This leads to an accumulation of partial glycerides and free fatty acids in milk. Short free fatty acids (Scanlan et al., 1965; Moio et al., 1993; Bendall, 2001) are responsible for rancid flavor, unacceptable for consumers, in milk and dairy products such as butter or fresh cream. Free fatty acids are also more susceptible to oxidation, responsible for deterioration of the taste of milk products. Besides, partial glycerides impair milk functionality such as foaming and creaming abilities (Deeth, 2006). As a consequence, lipolysis is an important issue for dairy farms and dairy industries.

Three types of lipolysis are defined: spontaneous, induced, and microbial lipolysis. Spontaneous lipolysis (SL) is inherent to the cow and to the husbandry management. Induced lipolysis is a consequence of mechanical and thermal shocks during milking and storage. Microbial lipolysis is due to microorganism contaminations such as Pseudomonas (Toušová et al., 2013). Spontaneous lipolysis was widely studied in the 1980s, and it was pointed out that SL depended mainly on feeding system, lactation or gestation stage, breed, and milking frequency (Cartier and Chilliard, 1990). A strong individual effect was also detected by Heuchel and Chilliard (1988): 30 to $40 \%$ of the variability of SL was explained by the individuals and this effect was repeatable from lactation to lactation. This suggested a potential genetic determinism of SL. 
A gene, DGAT1, coding for the enzyme diglyceride acyltransferase 1 (DGAT1), catalyzes the last step of triglycerides synthesis in the mammary gland. Cases et al. (1998) identified the DGAT1 K232A polymorphism in bovine species. A dinucleotide substitution of adenine and adenine (A-A) by guanine and cytosine (G-C) led to a replacement of Lys by Ala in the amino acid chain of the enzyme, changing its functional properties. Besides, milk composition has been shown to be modulated by DGAT1 genotypes. The DGAT1 K232 allele is associated with higher fat yield, higher fat content, lower protein yield, higher protein content, and lower milk yield (Grisart et al., 2002; Spelman et al., 2002 ). The DGAT1 K232A is also known to modulate milk fatty acid composition: DGAT1 K232 allele is associated with a larger fraction of SFA and C16:0 and smaller fractions of C14:0, unsaturated C18, and CLA (Schennink et al., 2007). It also modulates protein composition: DGAT1 K232 allele is associated with lower $\alpha_{S_{1}-}$ CN with 9 phosphorylated serine residues (Bijl et al., 2014; Boichard et al., 2014). The DGAT1 gene has a strong effect on milk fat content and composition and, therefore, could also modulate SL.

It is also well known that environmental factors and husbandry management, such as milking frequency, can modulate gene expression. In the mammary gland tissue, once-daily milking (ODM) modulates gene expression, leading to a downregulation of secretory activity (Littlejohn et al., 2010; Boutinaud et al., 2013). Lipoprotein lipase gene is downregulated upon ODM (Littlejohn et al., 2010; Boutinaud et al., 2013) and ODM is associated with lower SL (Rémond and Pomiès, 2005; Pomiès et al., 2007). Environmental and husbandry management could modulate gene expression differently according to gene genotypes. Hence, by changing milking frequency, gene expression could be modulated differently according to DGAT1 genotypes, leading to different component contents and different levels of SL. The objective of the current study was to evaluate the effect of DGAT1 K232A polymorphism on milk production traits and particularly on milk SL in a context of milking frequency variations.

\section{MATERIALS AND METHODS}

\section{Animals, Experimental Design, and Diets}

Twenty-one multiparous Holstein $\times$ Normande crossbred dairy cows in mid lactation were used. Lactation stage at the beginning of the trial was $81 \pm 9 \mathrm{~d}$. Cows were divided into 3 groups according to their DGAT1 K232A genotypes. The DGAT1 K232A genotypes were designated as follows: homozygous $K K$, heterozygous
$K A$, or homozygous $A A$. Eight cows had the $K K$ genotype ( $K K$ cows), 8 cows had the $K A$ genotype ( $K A$ cows), and 5 cows had the $A A$ genotype ( $A A$ cows). All cows were kept indoors with an average area of $10 \mathrm{~m}^{2}$ per cow.

The experiment consisted of 3 successive periods: (1) 3 control weeks of twice-daily milking (TDM1), (2) $3 \mathrm{wk}$ of ODM, and (3) $4 \mathrm{wk}$ of twice-daily milking (TDM2) to examine residual effects. Cows were milked at 0645 and $1630 \mathrm{~h}$ in TDM situations and at $0745 \mathrm{~h}$ in ODM situations.

Cows were fed in groups, and the diet was formulated to meet the requirements of TDM cows (Institut National de la Recherche Agronomique, 1989). Cows were given a complete diet composed of corn silage fed ad libitum, grass silage (4 $\mathrm{kg}$ of $\mathrm{DM} / \mathrm{d}$ ), dehydrated beet pulp ( $2 \mathrm{~kg}$ of DM/d), and soybean meal $(2 \mathrm{~kg}$ of $\mathrm{DM} / \mathrm{d})$. In addition, cows received $1 \mathrm{~kg}$ of concentrate (30\% corn, $29 \%$ barley, $13 \%$ soybean meal, $10 \%$ wheat, $10 \%$ wheat bran, $4 \%$ molasses, and $4 \%$ of minerals) for each $2.5 \mathrm{~kg}$ of milk produced daily above $22 \mathrm{~kg}$ of milk yield. Animals were weighted and BCS was recorded using the French notation scale of 0 to 5 (Bazin, 1984) at the end of every period (TDM1, ODM, TDM2).

\section{Genotyping}

Genotyping was performed on blood samples for all animals of the trial. The DGAT1 K232A polymorphism was genotyped with the Illumina Infinium BovineLD BeadChip (Illumina, San Diego, CA; Boichard et al., 2012).

\section{Milk Yield}

Milk yield was recorded every day at each milking. For TDM1, the average daily milk production was calculated on the basis of 3 wk for each cow. For ODM, we show data at $\mathrm{d} 1,2,7$, and 15 of the experiment, with d 0 corresponding to the first day of ODM. During TDM2, we show data at d 36 and 49.

\section{Sampling}

Milk Samples. Milk samples were obtained by milking the cows on milk cans at d $-20,-18,-13,-11$, $-6,-4$ (TDM1 period), 1, 2, 7, 15, 36, and 49 of the experiment, where d 0 was the first day of ODM. In TDM situations, milk collected at morning and evening milkings was pooled in 60:40 proportions. At each milking, we collected 3 vials of $50 \mathrm{~mL}$ of milk for laboratory analyses. Samples for milk composition analyses were kept at $4^{\circ} \mathrm{C}$ immediately after milking until analyzed. 
In ODM situation, we collected 3 vials of $50 \mathrm{~mL}$ of milk during the morning milking.

Blood Samples. Tail blood samples were collected using 5-mL heparinized tubes (VT-050SHL, Venoject, Terumo Europe, Leuven, Belgium) after morning milking on $\mathrm{d}-4$ (TDM1), 1, 2, and 15 of the experiment. Blood was centrifuged at $2,264 \times g$ for $15 \mathrm{~min}$ at $4^{\circ} \mathrm{C}$, and plasma was removed and stored at $-20^{\circ} \mathrm{C}$ until analysis.

\section{Laboratory Analyses}

Milk composition analyses were performed from the first vial of $50 \mathrm{~mL}$ at the Normandy Interprofessional Milk Analysis Laboratory (LILANO, Saint-Lô, France). Milk fat and protein contents were determined for each day of sampling. For TDM1, the average protein and fat contents were calculated on the basis of the 6 samplings during the 3 wk of TDM1. Milk lactose content, SCC, SFA, C16:0, C18:0, UFA, C18:1, PUFA, total casein, $\beta-\mathrm{CN}, \alpha_{\mathrm{S}^{-}} \mathrm{CN}, \alpha_{\mathrm{S}^{-}} \mathrm{CN}$, and $\kappa-\mathrm{CN}$ contents were determined for $\mathrm{d}-4,1,2,7,15,36$, and 49 . These analyses were performed by mid-infrared spectrometry (MilkoScan FT6000, Foss, Hillerød, Denmark; FerrandCalmels et al., 2014; Gelé et al., 2014) and SCC by flow cytometry. The 2 others vials per cow were collected to calculate SL by the difference between free fatty acid contents after $24 \mathrm{~h}$ of storage at $4^{\circ} \mathrm{C}$ and initial free fatty acid contents. Immediately after milking, a $50-\mathrm{mL}$ sample was heated in a water bath at $100^{\circ} \mathrm{C}$ for $2.5 \mathrm{~min}$ to stop lipase activity and then kept at $4^{\circ} \mathrm{C}$. A second sample was stored at $4^{\circ} \mathrm{C}$ for $24 \mathrm{~h}$, then heated and kept at $4^{\circ} \mathrm{C}$ in the same way. Free fatty acid analyses were performed on both samples by copper soap method (Shipe et al., 1980). Spontaneous lipolysis was determined at $\mathrm{d}-4,1,2,7,15$, and 36. Plasma lactose, glucose, urea, acetate, nonesterified fatty acids, and BHB contents were assayed using colorimetric enzymatic reaction on 2 replicates as reported in Delamaire and Guinard-Flament (2006).

\section{Calculation and Statistical Analyses}

All statistical analyses on the data set for the 21 cows were performed using SAS software (version 9.2, SAS Institute Inc., Cary, NC). The statistical significance threshold was set to $P<0.05$. Trend was set to $P<$ 0.10 . Normality of data was checked using the ShapiroWilk test of the SAS package univariate procedure.

The effects on the DGAT1 genotyped cows of TDM, ODM, and TDM switches on milk yield, milk composition, and blood composition were analyzed using the SAS MIXED procedure for repeated measures, according to the statistical model:
$\mathrm{Y}_{i j}=\mu+\operatorname{group}_{i}+\operatorname{period}_{j}+\operatorname{group}_{i} \times \operatorname{period}_{j}+\varepsilon_{i j}$,

where $\mu$ is the mean and $\mathrm{Y}_{i j}$ is the dependent variable on the fixed effects of group $i(K K, K A, A A)$ during period $j$ (TDM1, d 1, 2, 7, 15, 36, and 49) and their interactions, and $\varepsilon_{i j}$ is the residual error associated with each $i j$ observation.

\section{RESULTS}

\section{Effect of DGAT1 K232A Polymorphism During TDM1}

Milk Yield and Composition. Milk yield was significantly lower for $K K$ and $K A$ cows compared with $A A$ cows $(-5.3$ and $-5.0 \mathrm{~kg}$, respectively; Table 1$)$. Milk protein content and milk fat content tended to be higher for $K K$ and $K A$ cows compared with $A A$ cows $[0.24$ and $0.18 \%$ for protein content $(P=0.074)$ and 0.63 and $0.49 \%(P=0.082)$ for fat content, respectively]. No difference in milk lactose content and SCC was noted between groups. Percentages of SFA, MUFA, PUFA, and C16:0 and C18:0 were not significantly different between groups. Percentage of C18:1 tended to be higher for $K A$ cows (2.2 and $1.7 \%$ compared with $K K$ and $A A$ cows, respectively; $P=0.097)$. $\kappa$-Casein percentage was higher for $K K$ and $K A$ cows compared with $A A$ cows ( 0.8 and $0.5 \%$, respectively). We observed no difference in total casein, $\beta-\mathrm{CN}, \alpha_{\mathrm{S}^{-}} \mathrm{CN}$, and $\alpha_{\mathrm{S}_{2}}-\mathrm{CN}$ percentage. $\alpha_{\mathrm{S}_{1}}$-Casein and $\kappa$-CN contents were also higher for $K K$ and $K A$ cows compared with $A A$ cows (0.9 and $0.5 \mathrm{~g} / \mathrm{L}$ vs. 0.7 and $0.4 \mathrm{~g} / \mathrm{L}$, respectively).

$\boldsymbol{S L}$. Spontaneous lipolysis was twice higher for $K K$ cows (1.13 vs. 0.59 and $0.63 \mathrm{mEq} / 100 \mathrm{~g}$ of fat, respectively, for $K K, K A$, and $A A$ cows), although we noted no difference in initial free fatty acids (Table 1 ).

Plasma Parameters. Plasma nonesterified fatty acids, glucose, urea, and acetate contents were not significantly different. $\beta$-Hydroxybutyrate content was higher for $K A$ cows $(206.9$ and $296.8 \mu \mathrm{mol} / \mathrm{L}$, respectively, compared with $K K$ cows and $A A$ cows; $P=$ 0.031; Table 2)

Body Conditions. Weight and BCS were not significantly different (Table 3 ).

\section{Effect of DGAT1 K232A Polymorphism upon Milking Frequency Variations}

Milk Production and Composition. Milk production decreased during the period of ODM. At d 7, compared with TDM1, the differences reached -7.3 , -4.5 , and $-9.0 \mathrm{~kg} / \mathrm{d}$ for $K K, K A$, and $A A$ cows, respectively (Table 4). Cow milk production remained lower during TDM2 compared with TDM1 regardless of the DGAT1 K232A polymorphism (-3.0, -2.6, and 
Table 1. Effect of DGAT1 K232A polymorphisms on milk production and milk composition during twice-daily milking 1

\begin{tabular}{|c|c|c|c|c|c|}
\hline Item & $K K$ & $K A$ & $A A$ & $\mathrm{RMSE}^{1}$ & Effect \\
\hline Milk yield (kg) & $26.2^{\mathrm{a}}$ & $26.5^{\mathrm{a}}$ & $31.5^{\mathrm{b}}$ & 3.71 & 0.046 \\
\hline $\mathrm{SCC}\left(\times 10^{3} / \mathrm{mL}\right)$ & 59 & 44 & 107 & 3.5 & 0.341 \\
\hline Initial $\mathrm{FFA}^{2}$ & 0.22 & 0.23 & 0.24 & 0.104 & 0.924 \\
\hline Spontaneous lipolysis $^{2}$ & $1.13^{\mathrm{a}}$ & $0.59^{\mathrm{b}}$ & $0.63^{\mathrm{b}}$ & 0.550 & 0.035 \\
\hline \multicolumn{6}{|l|}{ Milk macronutrients } \\
\hline Fat content $(\%)$ & $4.05^{\mathrm{a}}$ & $3.91^{\mathrm{a}}$ & $3.42^{\mathrm{b}}$ & 0.454 & 0.074 \\
\hline Protein content (\%) & $3.09^{\mathrm{a}}$ & $3.03^{\mathrm{a}}$ & $2.85^{\mathrm{b}}$ & 0.173 & 0.082 \\
\hline Fat yield $(\mathrm{g} / \mathrm{d})$ & 1057 & 1027 & 1069 & 153.3 & 0.876 \\
\hline Protein yield (g/d) & 810 & 801 & 899 & 162.8 & 0.364 \\
\hline Lactose $(\%)$ & 5.04 & 5.03 & 5.24 & 0.106 & 0.367 \\
\hline \multicolumn{6}{|c|}{ Milk fatty acids proportion (\%) } \\
\hline SFA & 74.6 & 72.0 & 75.6 & 2.97 & 0.181 \\
\hline MUFA & 23.8 & 26.3 & 23.8 & 2.51 & 0.214 \\
\hline PUFA & 4.4 & 4.5 & 4.7 & 1.25 & 0.950 \\
\hline C16:0 & 35.9 & 32.9 & 35.9 & 2.54 & 0.105 \\
\hline C18:0 & 9.8 & 10.0 & 9.4 & 1.13 & 0.723 \\
\hline $\mathrm{C} 18: 1$ & 17.1 & 19.3 & 17.6 & 1.68 & 0.097 \\
\hline \multicolumn{6}{|c|}{ Milk protein content $(\mathrm{g} / \mathrm{L})$} \\
\hline Total casein & $26.3^{\mathrm{a}}$ & $25.8^{\mathrm{a}}$ & $23.8^{\mathrm{b}}$ & 1.66 & 0.048 \\
\hline$\beta-\mathrm{CN}$ & 10.6 & 10.6 & 9.8 & 0.73 & 0.169 \\
\hline$\alpha_{\mathrm{S} 1}-\mathrm{CN}$ & $8.4^{\mathrm{a}}$ & $8.2^{\mathrm{a}}$ & $7.5^{\mathrm{b}}$ & 0.51 & 0.017 \\
\hline$\alpha_{\mathrm{S} 2^{-}} \mathrm{CN}$ & 3.5 & 3.4 & 3.2 & 0.28 & 0.301 \\
\hline$\kappa-\mathrm{CN}$ & $3.4^{\mathrm{a}}$ & $3.3^{\mathrm{a}}$ & $2.9^{\mathrm{b}}$ & 0.28 & 0.009 \\
\hline \multicolumn{6}{|c|}{ Milk protein proportion (\%) } \\
\hline Total casein & 83.0 & 83.1 & 82.7 & 1.45 & 0.875 \\
\hline$\beta-\mathrm{CN}$ & 33.5 & 33.9 & 34.1 & 1.31 & 0.397 \\
\hline$\alpha_{\mathrm{S} 1}-\mathrm{CN}$ & 26.5 & 26.4 & 26.0 & 0.65 & 0.833 \\
\hline$\alpha_{\mathrm{S} 2}-\mathrm{CN}$ & 11.0 & 11.0 & 11.2 & 0.67 & 0.680 \\
\hline$\kappa-\mathrm{CN}$ & $10.8^{\mathrm{a}}$ & $10.5^{\mathrm{a}}$ & $10.0^{\mathrm{b}}$ & 0.50 & 0.029 \\
\hline
\end{tabular}

${ }_{\mathrm{a}, \mathrm{b}}$ Means in the same row with no common superscript differ $(P<0.05)$.

${ }^{1} \mathrm{RMSE}=$ root mean square error

${ }^{2} \mathrm{mEq} / 100 \mathrm{~g}$ of fat. FFA $=$ free fatty acids.

$-3.6 \mathrm{~kg}$ for $K K, K A$, and $A A$ cows, respectively). Milk fat content increased in the 3 groups upon ODM $(1.12$, 0.85 , and $1.02 \%$, respectively, for $K K, K A$, and $A A$ cows at $\mathrm{d} 7$ ) and remained higher at $\mathrm{d} 36$ than in TDM1. At d 15, no significant difference was found between $K K$, $K A$, and $A A$. No significant differences were found between d 49 and TDM1. During the whole experimental period fat content was higher in $K K$ cows (0.61 and $0.62 \%$ compared with $K A$ and $A A$, respectively). In all groups, milk protein content slightly decreased at d 2, increased from d $7(0.12,0.11$, and $0.21 \%$ for $K K$, $K A$, and $A A$ cows, respectively, at $\mathrm{d} 7$ ) and remained higher at d 36 than in TDM1. Fat and protein contents followed the same trend in ODM: they had a transitory period at $\mathrm{d} 1$ and 2 and reached equilibrium at $\mathrm{d} 7$ and 15. Milk lactose content decreased upon ODM in the 3 groups $(-0.34,-0.38$, and $-0.33 \%$ for $K K, K A$, and $A A$ cows, respectively) and was higher for $A A$ cows (0.25 and $0.23 \%$, respectively, for $K K$ and $K A$ cows). Somatic cell count increased upon ODM regardless of the DGAT1 K232A polymorphism.

Monounsaturated fatty acids, C18:1, and PUFA decreased regardless of the DGAT1 K232A polymorphism during ODM period $(-1.6 \%$ for MUFA, $-1.46 \%$ for

Table 2. Effect of DGAT1 K232A polymorphisms on plasma parameters during twice-daily milking 1

\begin{tabular}{lccccc}
\hline Item & $K K$ & $K A$ & $A A$ & RMSE $^{1}$ & Effect \\
\hline NEFA $^{2}(\mu \mathrm{mol} / \mathrm{L})$ & 85 & 112 & 92 & 39.5 & 0.380 \\
BHB $(\mu \mathrm{mol} / \mathrm{L})$ & $625^{\mathrm{b}}$ & $832^{\mathrm{a}}$ & $535^{\mathrm{b}}$ & 19.6 & 0.031 \\
Glucose $(\mathrm{mg} / \mathrm{dL})$ & 67.2 & 62.2 & 65.1 & 6.77 & 0.362 \\
Acetate $(\mathrm{mmol} / \mathrm{L})$ & 1.04 & 1.30 & 1.23 & 0.305 & 0.257 \\
Urea $(\mathrm{mg} / \mathrm{dL})$ & 18.5 & 16.3 & 17.2 & 6.02 & 0.771 \\
\hline
\end{tabular}

a,b Means in the same row with no common superscript differ $(P<0.05)$.

${ }^{1} \mathrm{RMSE}=$ root mean square error.

${ }^{2} \mathrm{NEFA}=$ nonesterified fatty acids. 
Table 3. Effect of DGAT1 K232A polymorphisms on body condition during twice-daily milking 1

\begin{tabular}{lccccc}
\hline Item & $K K$ & $K A$ & $A A$ & RMSE $^{1}$ & Effect \\
\hline Weight $(\mathrm{kg})$ & 649 & 665 & 607 & 49.0 & 0.142 \\
BCS & 2.5 & 2.8 & 2.3 & 0.50 & 0.203 \\
\hline
\end{tabular}

${ }^{1} \mathrm{RMSE}=$ root mean square error.

C18:1, and -1.04 for PUFA) compared with TDM1. At d 36, compared with ODM and TDM1, SFA (particularly C16:0) increased $(0.9,2.1$, and 1.2 for $\mathrm{C} 16: 0$ for $K K, K A$, and $A A$ cows, respectively), MUFA, C18:1, and PUFA decreased $(-2,-3.3$, and $-2.7 \%$ for $\mathrm{C} 18: 1$ for $K K, K A, A A$ cows, respectively) and C18:0 also decreased (Table 5).

We observed an interaction between milking frequency and DGAT1 K232A polymorphism for total casein percentage. At d 1, total casein percentage increased less for $K K$ and $K A$ cows than for $A A$ cows (respectively, 1.1, 1.9, and $2.9 \%$ ) and was lower for $K K$ and $K A$ cows in ODM. At d 36, we found no difference in total casein percentage according to DGAT1 K232A polymorphism. However, no interaction was noted between DGAT1 K232A polymorphism and milking frequency for total casein content. Regardless of DGAT1 $\mathrm{K} 232 \mathrm{~A}$ polymorphism, $\kappa$ - and $\alpha_{\mathrm{S}_{2}} \mathrm{CN}$ percentages were lower and $\beta$ - and $\alpha_{S_{1}}$-CN percentages were higher during ODM than TDM1 (respectively, -0.34 and -1.16 , and 0.50 and $1.50 \%$ at $\mathrm{d} 7$ compared with TDM1) and remained higher at $\mathrm{d} 36$. $\beta$-Casein percentage increased at $\mathrm{d} 1(1.5 \%)$, and decreased at d 2 and $7(-1.2 \%$ com- pared with d 1), but remained higher than in TDM1 and increased at $\mathrm{d} 36 . \kappa$-Casein percentage decreased at d $1(-0.8 \%)$ and increased at d 2 and 7 (1\% compared with d 1), but remained lower than in TDM1 and decreased at $\mathrm{d} 36 . \alpha_{\mathrm{S}_{2}}$ Casein percentage decreased at $\mathrm{d}$ 1 and remained lower at $\mathrm{d} 2,7$, and 36 than in TDM1 $\left(-1.2 \%\right.$ at $\mathrm{d} 7$ and 36 compared with TDM1). $\alpha_{\mathrm{S}^{-}}$ Casein percentage increased during ODM $(1.6 \%$ at $\mathrm{d}$ $7)$, and decreased at d $36(-1 \%$ compared with $\mathrm{d} 7)$ but remained higher than TDM1. For $K K$ and $K A$ cows, $\kappa-\mathrm{CN}$ percentage was higher and $\beta-\mathrm{CN}$ lower than for $A A$ cows during the whole experimental period $(-0.5$ and $-0.4 \%$ for $\kappa-\mathrm{CN}$ and 1 and $1 \%$ for $K K$ and $K A$ cows for $\beta-\mathrm{CN}$, respectively). Variations in $\beta-, \kappa^{-}, \alpha_{\mathrm{S}^{-}}$, and $\alpha_{\mathrm{S} 1}-\mathrm{CN}$ contents were parallel to the variations of protein contents (Table 5).

Milk SL. Milk SL sharply decreased during ODM and did not significantly differ among the 3 groups of cows during the ODM period (below $0.2 \mathrm{mEq} / 100 \mathrm{~g}$ of fat after d 7), although SL was higher for $K K$ cows during TDM1. At d 36, SL was increased compared with ODM and was higher for $K K$ cows $(0.41$ vs. 0.21 and $0.27 \mathrm{mEq} / 100 \mathrm{~g}$ of fat, respectively, for $K K, K A$, and

Table 4. Effect of DGAT1 K232A polymorphisms on milk production and macronutrients upon milking frequency variations

\begin{tabular}{|c|c|c|c|c|c|c|c|c|c|c|c|}
\hline Item & $\begin{array}{l}\text { Twice daily } \\
\text { milking } 1\end{array}$ & d 1 & d 2 & d 7 & d 15 & d 36 & d 49 & $\mathrm{RMSE}^{1}$ & \multicolumn{3}{|c|}{ Effects } \\
\hline Milk yield (kg) & & & & & & & & 2.09 & $<0.001$ & 0.137 & 0.280 \\
\hline$K A$ & 26.5 & 19.9 & 18.4 & 22.0 & 22.6 & 25.3 & 23.9 & & & & \\
\hline$A A$ & 31.5 & 22.1 & 20.3 & 22.5 & 23.8 & 28.8 & 27.9 & & & & \\
\hline Fat (\%) & & & & & & & & 0.844 & $<0.001$ & 0.003 & 0.487 \\
\hline$A A$ & 3.42 & 4.41 & 6.52 & 4.44 & 4.50 & 4.37 & 3.14 & & & & \\
\hline Fat yield (g/d) & & & & & & & & 260.9 & $<0.001$ & 0.234 & 0.823 \\
\hline$K K$ & 1,057 & 964 & 1,127 & 972 & 1,196 & 1,291 & 914 & & & & \\
\hline$K A$ & 1,027 & 928 & 948 & 1,056 & 951 & 1,175 & 818 & & & & \\
\hline$A A$ & 1,068 & 964 & 1,335 & 995 & 1,304 & 1,280 & 874 & & & & \\
\hline Protein (\%) & & & & & & & & 0.217 & $<0.001$ & 0.132 & 0.513 \\
\hline$K K$ & 3.09 & 3.04 & 3.09 & 3.21 & 3.16 & 3.35 & 3.40 & & & & \\
\hline$A A$ & 898 & 603 & 577 & 681 & 710 & 889 & 874 & & & & \\
\hline
\end{tabular}

${ }^{1} \mathrm{RMSE}=$ root mean square error. 
VANBERGUE ET AL.

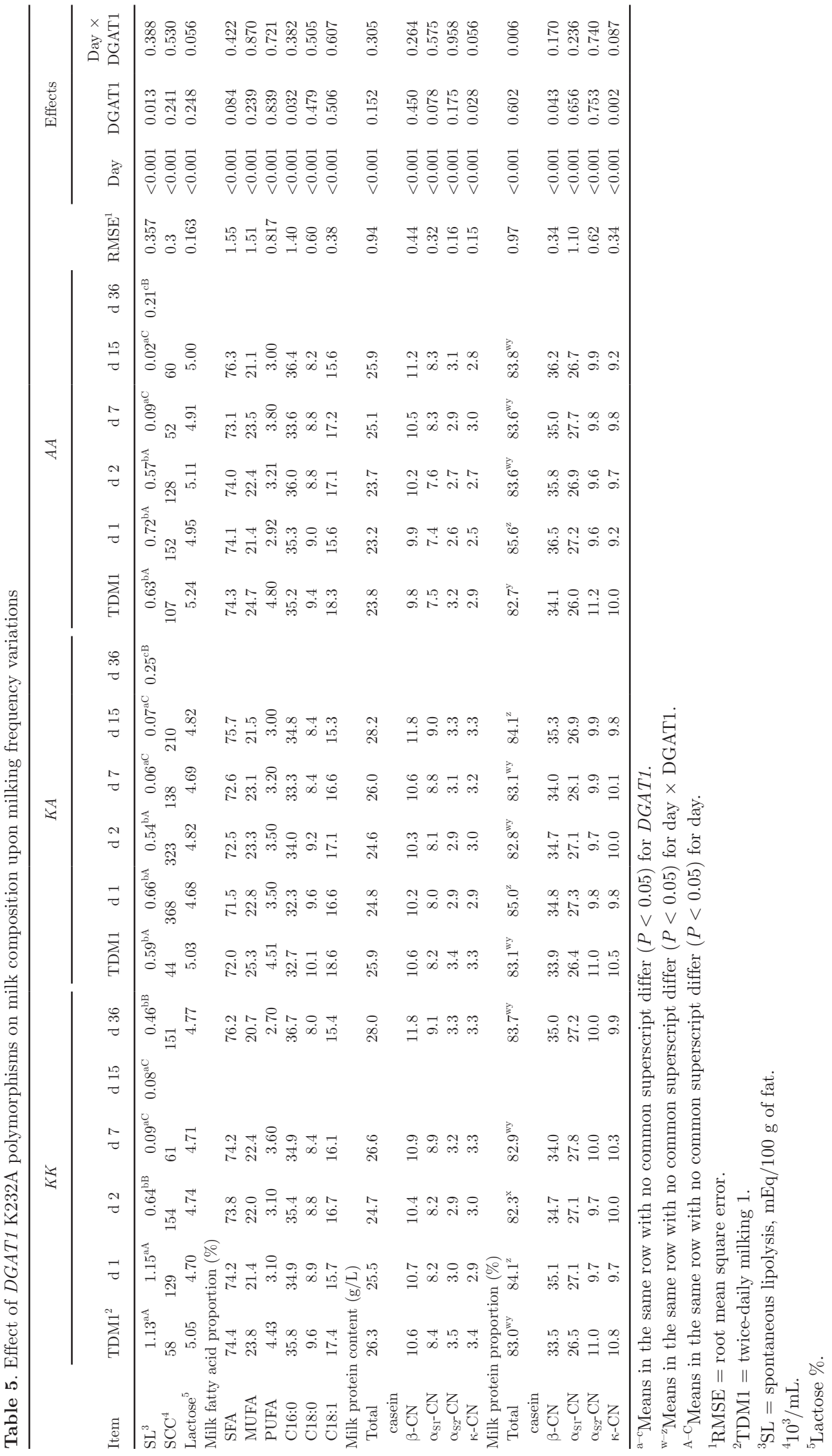


$A A$ cows). However, SL remained sharply lower than in TDM1 $(-0.67,-0.34$, and $-0.42 \mathrm{mEq} / 100 \mathrm{~g}$ of fat, respectively, for $K K, K A$, and $A A$ cows)

Plasma Parameters. Evolution of nonesterified fatty acids, urea, acetate, and glucose was not significantly different according to DGAT1 K232A polymorphism. Nonesterified fatty acid content tended to decrease at $\mathrm{d} 2(-22.3 \mu \mathrm{mol} / \mathrm{L})$ and increased at $\mathrm{d} 15$. At d 15, nonesterified fatty acid content was not significantly different from nonesterified fatty acid content in TDM1 (96.3 and $95.3 \mu \mathrm{mol} / \mathrm{L}$ for TDM1 and $\mathrm{d} 15$, respectively). Uremia decreased at $\mathrm{d} 1$ and $2(-9.1 \mathrm{mg} /$ $\mathrm{dL}$ for $\mathrm{d} 2$ compared with TDM1) and increased at $\mathrm{d}$ 15. At d 15, uremia was not significantly different from uremia in TDM1 (17.3 and $19.2 \mathrm{mg} / \mathrm{dL}$ for TDM1 and d 15, respectively). Acetate content decreased at d 1 $(-0.27 \mathrm{mmol} / \mathrm{L})$ and was not significantly different at TDM1, d 2, and d 15 (respectively, 1.19, 1.27, and 1.16 $\mathrm{mmol} / \mathrm{L})$. Plasma glucose increased at d $1(8.5 \mathrm{mg} /$ $\mathrm{dL}$ ) and was not significantly different at TDM1, d 2, and d 15 (respectively, 64.5, 63.9, and $67.6 \mathrm{mg} / \mathrm{dL}$ ). $\beta$-Hydroxybutyrate content did not change upon ODM for $A A$ and $K K$ cows but decreased for $K A$ cows at d 1 $(-228 \mu \mathrm{mol} / \mathrm{L}$ compared with TDM1), increased at d $2(200 \mu \mathrm{mol} / \mathrm{L}$ compared with $\mathrm{d} 1)$, and decreased at d $15(-191 \mu \mathrm{mol} / \mathrm{L}$ compared with d 2; Table 6).

\section{DISCUSSION}

\section{Effect of DGAT1 K232A Polymorphism During TDM1}

Milk Yield and Composition. Effects of DGAT1 K232A polymorphism on milk yield, fat, and protein contents are consistent with the previous studies (Grisart et al., 2002; Spelman et al., 2002; Thaller et al., 2003; Schennink et al., 2007). It should be noted that mean lactation stage of our cows was $81 \pm 9 \mathrm{~d}$ and that DGAT1 K232A polymorphism effects on milk traits are the strongest in that period of lactation (Bovenhuis et al., 2015). Compared with $K A$ and $A A$ genotypes, the $K K$ genotype was associated with a lower milk production, higher protein content, and higher fat content, although these results were only trends in our experiment given the relatively low number of cows and the constraints of the experimental design. Contrary to Bovenhuis et al. (2015), we did not find a significant effect on lactose content in TDM situations although lactose content was numerically higher when associated with the $A A$ genotype. Contrary to Schennink et al. (2007), we showed few differences in fatty acid composition; this could be explained by the low number of animals combined with the use of the mid-infrared spectrometry equation method (Ferrand-Calmels et al., 2014) for fatty acid determination. $\kappa$-Casein and $\alpha_{S 1}-\mathrm{CN}$ contents

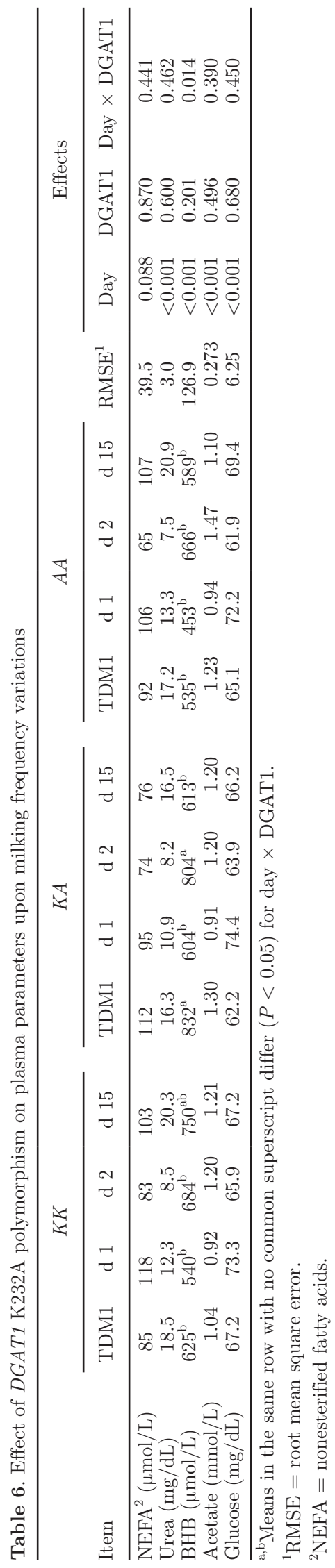

Journal of Dairy Science Vol. 99 No. 7, 2016 
were higher for $K K$ and $K A$ cows. Those results are not consistent with Schopen et al. (2011), who found that the DGAT1 232A allele was associated with a higher content of $\alpha_{\mathrm{S}^{-}} \mathrm{CN}$ and a lower content of $\alpha_{\mathrm{S}_{2}} \mathrm{CN}$. However, Bijl et al. (2014) found that the DGAT1 232A allele was only associated with a higher level of $\alpha_{\mathrm{S}_{1}} \mathrm{CN}$ with 9 phosphorylated serine residues $\left(\alpha_{\mathrm{S}_{1}} \mathrm{CN}-9 \mathrm{P}\right)$, although $\alpha_{\mathrm{S}^{-}} \mathrm{CN}$ with 8 phosphorylated serine residues $\left(\alpha_{\mathrm{S} 1}-\mathrm{CN}-8 \mathrm{P}\right)$ was regulated by other gene genotypes, such as $\beta$-LG. This can explain the differences in $\alpha_{\mathrm{S1}^{-}}$ $\mathrm{CN}$ content in both trials. According to Boichard et al. (2014), DGAT1 would regulate the expression of all milk caseins, but would only explain 3 to $11 \%$ of the genetic variance depending on type of casein and cow breed. Thus, an association between DGAT1 and protein composition exists, but it is small and variable depending on the regulation of other genes. The existence of gene polymorphism at the $L P L$ locus (Badaoui et al., 2007), in linkage disequilibrium with DGAT1, would be interesting to investigate.

Milk SL. The $K K$ genotype was associated with a milk SL twice as high as the $K A$ and $A A$ genotypes. The current study is, to our knowledge, the first to describe an association between milk SL and DGAT1 genotypes, but the results did not allow us to describe the mechanism, although we can put forward several assumptions. According to Cartier and Chilliard, (1990), biochemical factors better correlated with SL are (1) proportion of LPL linked to the milk fat globule membrane (MFGM), (2) MFGM integrity, and (3) balance between LPL activators and inhibitors. The DGAT1 K232A polymorphism might act through these 3 ways.

(1) In our trial, DGAT1 232A allele was associated with lower casein content and lower SL rate. Casein micelles and LPL are normally linked by electrostatic interactions in the skimmed fraction of milk (Deeth, 2006). Thus, variations in casein or LPL contents could modify the equilibrium between those components and, as a consequence, could modify the proportion of LPL linked to the MFGM upon cooling. Investigation of casein content in relation to SL enabled us to conclude that lower casein content would not enhance milk SL as expected.

(2) The MFGM integrity could be linked either to milk fat globule (MFG) size or MFG composition (Evers, 2004; Wiking et al., 2006; Dickow et al., 2011). Concerning MFG size, Wiking et al. (2006) showed that MFG size and SL happened to move in the same direction, although direct correlation was not established, and Argov Argaman et al. (2013) showed that DGAT1 KK genotype was associated with larger MFG. However, in previous trials, we found no correlation between MFG size and SL $\left(\mathrm{n}=600, \mathrm{R}^{2}=0.14\right.$; data not shown); thus, MFG size might not be considered as an explicative variable. The DGAT1 K232 allele would be associated with higher stomatin and sphingomyelin contents in MFGM (Argov-Argaman et al., 2013; Lu et al., 2015), which are components of lipid rafts on the MFGM (Lopez et al., 2010). These rafts could facilitate the interactions between LPL and MFGM. The differences in MFGM composition would be the most susceptible way to explain variations in milk SL rates.

(3) Lu et al. (2015) analyzed the variation of proteome and did not mention any variation of proteose peptone 3 , an inhibitor of LPL activity, or proteose peptone 5, an activator of LPL activity (Chilliard et al., 1986). Activators and inhibitors of LPL did not seem to vary according to DGAT1 K232A polymorphism.

Plasma Parameters. The KA genotype was associated with higher level of BHB, which could be an indicator of higher lipid mobilization for those cows. This is consistent with the higher level of milk C18:1 detected for the $K A$ genotype. The $K A$ genotype would be associated with a different energy metabolism from $K K$ and $A A$ genotypes, with a higher negative energy balance. In the literature, plasma metabolic traits in relation to DGAT1 K232A polymorphism have been poorly studied and results are contradictory. Oikonomou et al. (2009) found that the DGAT1 232A allele had a favorable effect on energy balance during the entire lactation. On the contrary, Banos et al. (2008) found a marginal positive effect of K232 allele on energy balance. Bovenhuis et al. (2015) found no difference according to DGAT1 K232A polymorphism in energy outputs for multiparous cows during the whole lactation, although the $K A$ genotype was shown to increase energy outputs in primiparous cows. Finally, no direct link appeared between SL and lipid mobilization in the body.

\section{Effect of DGAT1 K232A Polymorphism upon Variations of Milking Frequency}

Milk Yield and Milk Composition. The effects of ODM on milk traits were not different according to DGAT1 K232A polymorphism. The effects of ODM on milk production and milk composition are consistent with the literature. Once daily milking is associated with lower milk production and higher fat concentration (Rémond et al., 2004; Pomiès et al., 2007; Stelwagen et al., 2013). Protein content decreased during the transition period of ODM (d 1 and 2), but was higher when the ODM equilibrium was reached (d 7 and 15; Rémond and Pomiès, 2005; Guinard-Flament et al., 2007). Few studies have evaluated the effect of ODM on milk fatty acid composition. Guinard-Flament et al. (2007) noticed no change in SFA proportion upon ODM. In our trial, the increase in SFA proportion could be linked to 
the potential improvement of energy status of the cows whose diet was formulated to cover TDM requirements even during ODM. The evolution of total casein percentage upon ODM was different according to DGAT1 K232A polymorphism: the K232 allele was associated with lower total casein percentage during ODM. The casein percentage transitorily decreased at d 2 for $K K$ and $K A$ genotypes of $D G A T 1$, as traditionally observed in dairy cows (Stelwagen et al., 2013), but it increased for $A A$ genotypes. The increase in total casein percentage for $A A$ genotypes may be due to lower whey protein concentration in ODM. The increase in whey proteins during the first days of ODM is due to tight junction permeability, which causes an influx of blood serum derivative proteins (Stelwagen et al., 1997). The $A A$ genotypes might be associated with higher mammary gland compliance. Otherwise, our results on the effect of ODM on total casein content were consistent with the literature: after a slight decrease in the transitory period, total casein increased upon ODM. Several studies reported an increase in total casein content by a concentration effect, a higher increase in whey protein content, and a decrease of the casein-to-whey protein ratio (Rémond and Pomiès, 2005; Guinard-Flament et al., 2007; Pomiès et al., 2007). $\beta$-Casein percentage increased and $\kappa-\mathrm{CN}$ percentage decreased upon ODM. Those results were consistent with the downregulation of $\kappa$-CN transcripts upon ODM, pointed out by Boutinaud et al. $(2008,2013)$. One week after the beginning of ODM, $\kappa-\mathrm{CN}$ transcripts decreased by $86 \%$. Yang et al. (2005) and Littlejohn et al. (2010) also showed a downregulation of $\beta$-CN upon ODM, with a slighter decrease of the number of transcripts (20\%).

Milk SL. Milk SL decreased upon ODM regardless of the DGAT1 K232A polymorphism, suggesting that LPL could become a limiting factor in ODM situations because of mammary gland activity downregulation. Otherwise, the decrease in SL upon ODM is consistent with the results of Rémond and Pomiès (2005) and Pomiès et al. (2007), who reported a $67 \%$ decrease in free fatty acid content in milk and a $27 \%$ decrease in lipolytic activity that would partly explain the decrease in free fatty acid content. A decrease in the number of LPL transcripts upon ODM has also been reported by Littlejohn et al. (2010) and Boutinaud et al. (2013). No information is available, to our knowledge, about the effect of ODM on MFGM composition or LPL activators and inhibitors. Spontaneous lipolysis increased during the second period of TDM, and hierarchy between $K K, K A$, and $A A$ genotypes had been re-established although SL rates remained sharply lower than in the first period of TDM, which indicates residual effects of ODM on SL. Although the residual effects of ODM after resume to TDM on milk yield had been studied
(Stelwagen et al., 2013), few data on milk components evolution that could explain SL are available (Rémond and Pomiès, 2005).

Plasma Parameters. Contrary to the literature (Guinard-Flament et al., 2007), plasma glucose and nonesterified fatty acids did not considerably change during ODM regardless of the DGAT1 K232A polymorphism. At d 15, BHB was not significantly different between groups, although the $K A$ genotype was associated with a higher level of BHB in TDM1. Milk C18:1 was lower during ODM, whatever the DGAT1 K232A polymorphism. Judging from milk C18:1, lipid mobilization seemed to decrease upon ODM regardless of the DGAT1 K232A polymorphism. This would be consistent with the improvement of energy status during ODM previously noted (Stelwagen et al., 2013), but, as indicated by BHB, the decrease would be more accurate for $K A$ cows. As the metabolic indicators were divergent, we might be prudent on these conclusions.

\section{Implications}

We showed that DGAT1 K232A polymorphism has major effects on milk traits, casein composition, and milk SL. In TDM situations, the $K K$ genotype was associated with higher level of SL but also higher level of total fat and total casein; the $A A$ genotype was associated with lower level of SL, total fat, and total casein; and the $K A$ genotype was associated with lower level of SL and higher level of total fat and casein. According to the outlets of milk (i.e., drinking milk, butter, or cheese), specific characteristics are desirable. However, the $K A$ genotype seems to be a good intermediate between milk fat quality and cheesemaking aptitude. A larger study should be done to associate milk composition and quality with genetics to lead to animal selection.

We showed that ODM was associated with lower level of SL whatever the DGAT1 K232A genotype. Once daily milking is not commonly practiced in farms for economic reasons linked with milk losses. However, it has been shown that milk production does not differ when cows are milked once a day 8 wk before drying off (Ferris et al., 2008; Stelwagen et al., 2013) and that, in parallel, SL can dramatically increase during late lactation (Cartier and Chilliard, 1990). Once daily milking could be applied in late lactation to avoid the increase in SL.

\section{CONCLUSIONS}

The genotype $K K$ of $D G A T 1$ was associated with SL rates twice as high as than the $K A$ and $A A$ genotypes in TDM situations, suggesting that DGAT1 coding for the 
enzyme diglyceride acyltransferase 1 could also affect SL. It was not possible to clarify the causal mechanism at this stage. The trial also shows that the effect of DGAT1 K232A polymorphism on SL can be forced by husbandry practices, such as ODM, known to dramatically reduce SL.

\section{ACKNOWLEDGMENTS}

The authors thank the all staff (Sébastien Blandamour, Samuel Boulan, Bernard Camps, Yves Carbonnier, Jean-Luc Deust, Julien Gentil, Stéphane Gressin, Loïc Leloup, Denis Pichonat, and Laurent Vandenbroucke) of the experimental farm of le Pin-au-Haras (INRA, Domaine du Pin-au-Haras, Exmes, France) for the herd management and for their assistance with milk sampling. They are also grateful to LILANO (Laboratoire Interprofessionnel Laitier de Normandie, Saint-Lô, France) for technical assistance. Thanks are also due to the Join Technical Unit of Research and Ingeneering on dairy farming (UMT RIEL, Rennes, France) for the constructive exchanges. The authors also thank Gwen Christiansen [INRA-UMR Agroécologie innovation et territoire (AGIR), Castanet Tolosan, France] for her fine work correcting the English in the manuscript. This research received financial support from the $\mathrm{CN}$ IEL (Centre National Interprofessionnel de l'Economie Laitière, Paris, France).

\section{REFERENCES}

Argov-Argaman, N., K. Mida, B.-C. Cohen, M. Visker, and K. Hettinga. 2013. Milk fat content and DGAT1 genotype determine lipid composition of the milk fat globule membrane. PLoS ONE 8:e68707.

Badaoui, B., J. M. Serradilla, A. Tomas, B. Urrutia, J. L. Ares, J Carrizosa, A. Sanchez, J. Jordana, and M. Amills. 2007. Short communication: Identification of two polymorphisms in the goat lipoprotein lipase gene and their association with milk production traits. J. Dairy Sci. 90:3012-3017.

Banos, G., J. A. Woolliams, B. W. Woodward, A. B. Forbes, and M. P. Coffey. 2008. Impact of single nucleotide polymorphisms in leptin, leptin receptor, growth hormone receptor, and diacylglycerol acyltransférase (DGAT1) gene loci on milk production, feed, and body energy traits of UK dairy cows. J. Dairy Sci. 91:3190-3200.

Bazin, S. 1984. Grille de notation de l'état d'engraissement des vaches Pie Noires. ITEB, Paris France.

Bendall, J. G. 2001. Aroma compounds of fresh milk from New Zealand cows fed different diets. J. Agric. Food Chem. 49:4825-4832.

Bijl, E., R. de Vries, H. van Valenberg, T. Huppertz, and T. van Hooijdonk. 2014. Factors influencing casein micelle size in milk of individual cows: Genetic variants and glycosylation of $\kappa$-casein. Int. Dairy J. 34:135-141.

Boichard, D., H. Chung, R. Dassonneville, X. David, A. Eggen, S. Fritz, K. J. Gietzen, B. J. Hayes, C. T. Lawley, T. S. Sonstegard, C. P. Van Tassell, P. M. Vanraden, K. Viaud, and G. R. Wiggans. 2012. Design of a bovine low-density SNP array optimized for imputation. PLoS ONE 7:e34130.

Boichard, D., A. Govignon-Gion, H. Larroque, C. Maroteau, I. Palhiere, G. Tosser-Klopp, R. Rupp, M. P. Sanchez, and M. Brochard.
2014. Genetic determinism of milk composition in fatty acids and proteins in ruminants, and selection potential. INRA Prod. Anim. $27: 283-298$.

Boutinaud, M., M. H. Ben Chedly, E. Delamaire, and J. GuinardFlament. 2008. Milking and feed restriction regulate transcripts of mammary epithelial cells purified from milk. J. Dairy Sci. 91:988998.

Boutinaud, M., L. Galio, V. Lollivier, L. Finot, S. Wiart, D. Esquerre, and E. Devinoy. 2013. Unilateral once daily milking locally induces differential gene expression in both mammary tissue and milk epithelial cells revealing mammary remodeling. Physiol. Genomics 45:973-985.

Bovenhuis, H., M. H. P. W. Visker, H. J. F. van Valenberg, A. J. Buitenhuis, and J. A. M. van Arendonk. 2015. Effects of the DGAT1 polymorphism on test-day milk production traits throughout lactation. J. Dairy Sci. 98:6572-6582.

Cartier, P., and Y. Chilliard. 1990. Spontaneous lipolysis in bovine milk: combined effects of nine characteristics in native milk. J. Dairy Sci. 73:1178-1186.

Cases, S. S. Smith, Y. Zheng, H. Myers, S. Lear, E. Sande, S. Novak, C. Collins, C. B. Welch, A. J. Lusis, S. K. Erickson II, and R. V. Farese. 1998. Identification of a gene encoding and acyl CoA:diacylglycerol acyltransferase, a key enzyme in triacylglycerol synthesis. Proc. Natl. Acad. Sci. USA 95:13018-13023.

Chilliard, Y., M. P. Chazal, and P. Cartier. 1986. Le point sur la lipolyse du lait. Revue des École Nationale d'Industrie Laitière 112:12-19.

Deeth, H. C. 2006. Lipoprotein lipase and lipolysis in milk. Int. Dairy J. $16: 555-562$

Delamaire, E., and J. Guinard-Flament. 2006. Longer milking intervals alters mammary epithelial permeability and the udder's ability to extract nutrients. J. Dairy Sci. 89:2007-2016.

Dickow, J. A., L. B. Larsen, M. Hammershøj, and L. Wiking. 2011 Cooling causes changes in the distribution of lipoprotein lipase and milk fat globule membrane proteins between the skim milk and cream phase. J. Dairy Sci. 94:646-656.

Evers, J. M. 2004. The milkfat globule membrane-Methodologies for measuring milkfat globule (membrane) damage. Int. Dairy J. 14:747-760.

Ferrand-Calmels, M., I. Palhiere, M. Brochard, O. Leray, J. M. Astruc, M. R. Aurel, S. Barbey, F. Bouvier, P. Brunschwig, H. Caillatt, M. Douguet, F. Faucon-Lahalle, M. Gelé, G. Thomas, J. M. Trommenschlager, and H. Larroque. 2014. Prediction of fatty acid profiles in cow, ewe, and goat milk by mid-infrared spectrometry J. Dairy Sci. 97:17-35.

Ferris, C. P., J. P. Frost, C. S. Mayne, M. S. McCoy, and D. J. Kilpatrick. 2008. A comparison of the direct and residual response of dairy cows to once or twice-daily milking, in late lactation. Livest. Sci. 114:305-314.

Gelé, M., S. Minery, J. M. Astruc, P. Brunschwig, M. Ferrand-Calmels, G. Lagriffoul, H. Larroque, J. Legarto, O. Leray, P. Martin, G. Miranda, I. Palhiere, P. Trossat, and M. Brochard. 2014. Large scale phenotyping and genotyping of milk fine composition in the cow, goat and ewe. INRA Prod. Anim. 27:255-268.

Grisart, B., W. Coppieters, F. Farnir, L. Karim, C. Ford, P. Berzi, N. Cambisano, M. Mni, S. Reid, P. Simon, R. Spelman, M. Georges, and R. Snell. 2002. Positional candidate cloning of a QTL in dairy cattle: Identification of a missense mutation in the bovine DGAT1 gene with major effect on milk yield and composition. Genome Res. 12:222-231.

Guinard-Flament, J., E. Delamaire, P. Lamberton, and J. L. Peyraud. 2007. Adaptations of mammary uptake and nutrient use to once-daily milking and feed restriction in dairy cows. J. Dairy Sci 90:5062-5072

Heuchel, V., and Y. Chilliard. 1988. Le point sur la lipolyse du lait de vache. ITEB, Paris, France.

Institut National de la Recherche Agronomique (INRA). 1989. Ruminant nutrition: Recommanded allowances and feed tables. $\mathrm{R}$. Jarrige, ed. John Libbey, London, UK.

Littlejohn, M. D.. C. G. Walker, H. E. Ward, K. B. Lehnert, R. G. Snell, G. A. Verkerk, R. J. Spelman, D. A. Clark, and S. R. Davis. 
2010. Effects of reduced frequency of milk removal on gene expression in the bovine mammary gland. Physiol. Genomics 41:21-32.

Lopez, C., M.-N. Madec, and R. Jimenez-Flores. 2010. Lipid rafts in the bovine milk fat globule membrane revealed by the lateral segregation of phospholipids and heterogeneous distribution of glycoproteins. Food Chem. 120:22-33.

Lu, J., S. Boeren, T. van Hooijdonk, J. Vervoort, and K. Hettinga. 2015. Effect of the DGAT1 K232A genotype of dairy cows on the milk metabolome and proteome. J. Dairy Sci. 98:3460-3469.

Moio, L., J. Dekimpe, P. Etievant, and F. Addeo. 1993. Neutral volatile compounds in the raw milks from different species. J. Dairy Res. 60:199-213.

Oikonomou, G., K. Angelopoulou, G. Arsenos, D. Zygoyiannis, and G. Banos. 2009. The effects of polymorphisms in the DGAT1, leptin and growth hormone receptor gene loci on body energy, blood metabolic and reproductive traits of Holstein cows. Anim. Genet. 40:10-17.

Pomiès, D., B. Martin, Y. Chilliard, P. Pradel, and B. Rémond. 2007. Once-a-day milking of Holstein and Montbéliarde cows for 7 weeks in mid-lactation. Animal 1:1497-1505.

Rémond, B., and D. Pomiès. 2005. Once-daily milking of dairy cows: A review of recent French experiments. Anim. Res. 54:427-442.

Rémond, B., D. Pomiès, D. Dupont, and Y. Chilliard. 2004. Oncea-day milking of multiparous Holstein cows throughout the entire lactation: Milk yield and composition, and nutritional status. Anim. Res. 53:201-212

Rupp, M. P. S., and M. Brochard. 2014. Genetic determinism of milk composition in fatty acids and proteins in ruminants, and selection potential. INRA Prod. Anim. 27:283-298.

Scanlan, R. A., L. A. Sather, and E. A. Day. 1965. Contribution of free fatty acids to the flavor of rancid milk. J. Dairy Sci. 48:1582-1584.

Schennink, A., W. M. Stoop, M. H. P. W. Visker, J. M. L. Heck, H. Bovenhuis, J. J. van der Poel, H. J. F. van Valenberg, and J. A.
M. van Arendonk. 2007. DGAT1 underlies large genetic variation in milk-fat composition of dairy cows. Anim. Genet. 38:467-473.

Schopen, G. C. B., M. H. P. W. Visker, P. D. Koks, E. Mullaart, J. A. M. van Arendonk, and H. Bovenhuis. 2011. Whole-genome association study for milk protein composition in dairy cattle. J. Dairy Sci. 94:3148-3158.

Shipe, W. F., G. F. Senyk, and K. B. Fountain. 1980. Modified copper soap solvent extraction method for measuring free fatty acids in milk. J. Dairy Sci. 63:193-198.

Spelman, R. J., C. A. Ford, P. McElhinney, G. C. Gregory, and R. G. Snell. 2002. Characterization of the DGAT1 gene in the New Zealand dairy population. J. Dairy Sci. 85:3514-3517.

Stelwagen, K., V. C. Farr, H. A. McFadden, C. G. Prosser, and S. R. Davis. 1997. Time course of milk accumulation-induced opening of mammary tight junctions, and blood clearance of milk components. Am. J. Physiol. 273:R379-R386.

Stelwagen, K., C. V. C. Phyn, S. R. Davis, J. Guinard-Flament, D. Pomiès, J. R. Roche, and J. K. Kay. 2013. Reduced milking frequency: Milk production and management implications. J. Dairy Sci. 96:3401-3413.

Thaller, G., W. Kramer, A. Winter, B. Kaupe, G. Erhardt, and R. Fries. 2003. Effects of DGAT1 variants on milk production traits in German cattle breeds. J. Anim. Sci. 81:1911-1918.

Toušová, R., L. Stádník, and J. Ducháček. 2013. Effects of season and time of milking on spontaneous and induced lipolysis in bovine milk fat. Czech J. Food Sci. 31:20-26.

Wiking, L., J. H. Nielsen, A. K. Båvius, A. Edvardsson, and K. Svennersten-Sjaunja. 2006. Impact of milking frequencies on the level of free fatty acids in milk, fat globule size, and fatty acid composition. J. Dairy Sci. 89:1004-1009.

Yang, J., B. Zhao, V. E. Baracos, and J. J. Kennelly. 2005. Effects of bovine somatotropin on $\beta$-casein mRNA levels in mammary tissue of lactating cows. J. Dairy Sci. 88:2806-2812. 